\title{
A new Antillean moth of the genus Enigmogramma Lafontaine \& Poole (Noctuidae, Plusiinae)
}

\author{
Vitor O. Becker ${ }^{1}$
}

\begin{abstract}
Enigmogramma antillea sp. n., from Puerto Rico and Cuba, is the second endemic Plusiinae recorded for the Antilles.

KEY WORDS. Enigmogramma, Plusiinae, taxonomy, Antilles
\end{abstract}

Eleven Plusiinae species are known to the Antilles, only one of them, Ctenoplusia calceolaris (Walker, [1858]), is endemic to the region. The second endemic species is described below in order to provide a name to be included in a forthcoming checklist of the Antillean Lepidoptera.

\section{Enigmogramma antillea sp. $\mathbf{n}$.}

Figs 1-3

Enigmogramma sp. Lafontaine \& Poole, 1991: 41.

Male (Fig. 3). 14-16 mm. Head, thorax and legs fuscous, scales tipped whitish; legs with articulations whitish, antennae pale brown, distal end of scape white below. Fore wings brown with slight purple hue, paler basad to antemedial line and along costa, above cell; area below cell, between antemedial and postmedial lines forming a square dark brown patch; pair of black dots between basal and antemedial lines; a U-shaped silvery mark below middle of cell, followed distad by a nearly rounded, solid silvery dot; termen bordered with a series of lunules in the vein interspaces, forming a waved line along margin; cilia pale brown. Hind wings gray, paler towards base; cilia pale. Abdomen pale gray, densely covered with long paler scales along sides, with a conspicous pair of long ochreus coremata on $6^{\text {th }}$ and $7^{\text {th }}$ segments; a double coremata between $8^{\text {th }}$ segment and genitalia.

Male genitalia (Figs 1,2). Uncus long, slender, slightly thickened distally; tip sharp-pointed. Tegumen wide. Valvae long, narrow, margins nearly parallel; clasper long, thin, sharp-pointed; clavus long, thin, reaching distal margin of juxta. Juxta shield-shaped, proximal margin forming a wide angle. Saccus long, margins nearly parallel, square proximad; vesica armed with two very long cornuti, the basal one curved, nearly half length of aedoeagus; ductus ejaculatorius five times as long as aedoeagus.

Material studied. Holotype male: PUERTO RICO, Maricao, 770 m, 12.VIII.1987, Becker, 67383 (VOB, Vitor O. Becker Collection). Partypes: 8 males, same data as holotype; 1 male CuBA, Pinar del Rio, Viñales, 27.IX.1989, Becker, 70073 (VOB).

1) Research Associate, Departamento de Zoologia, Universidade de Brasilia. P.O. Box 04525 , 70919-970 Brasilia, Distrito Federal, Brasil. E-mail: vbecker@rudah.com.br 


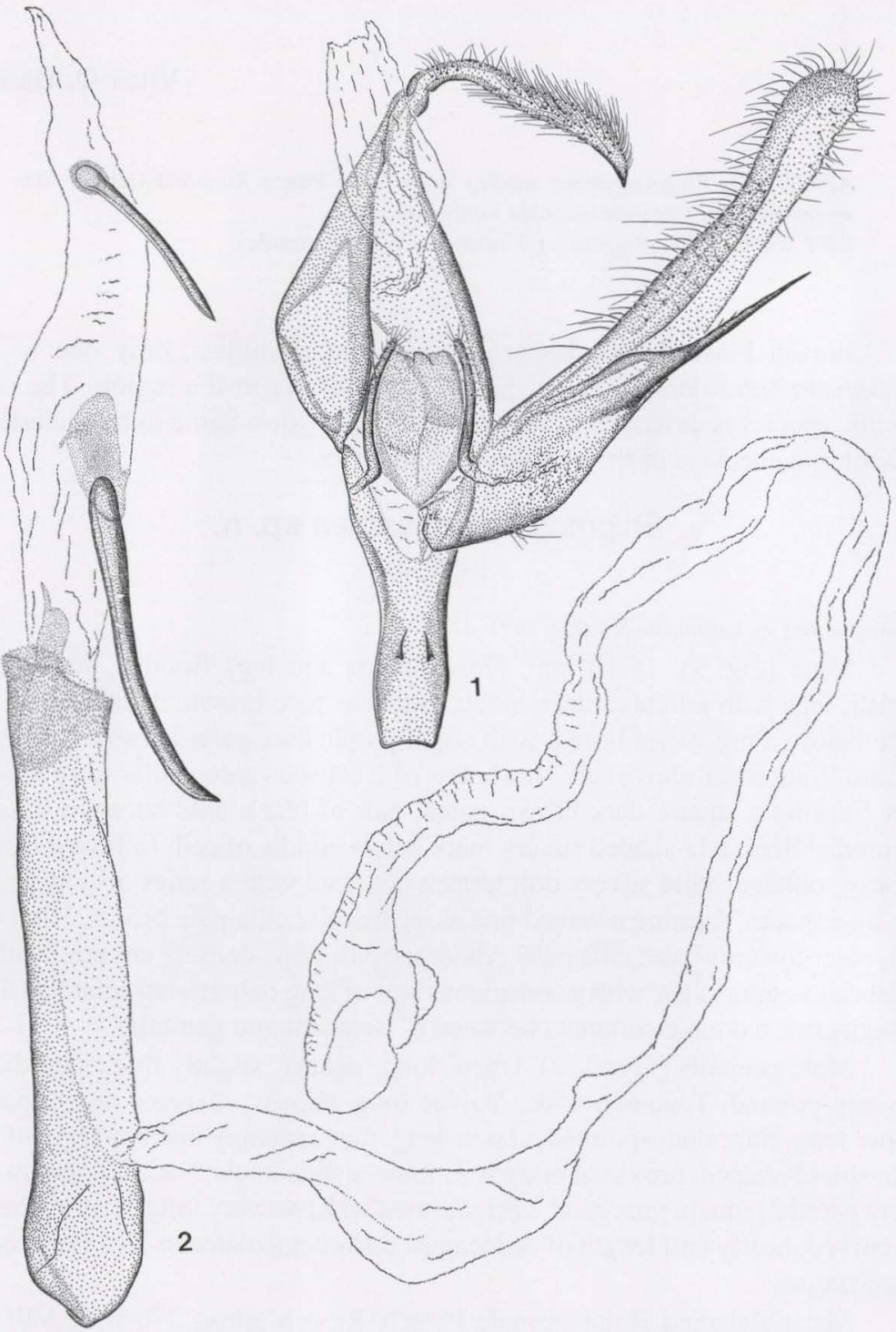

Figs 1-2. Enigmogramma antillea sp. n. (2) Male genialia with valva and aedoegus removed; (3) aedoeagus. 


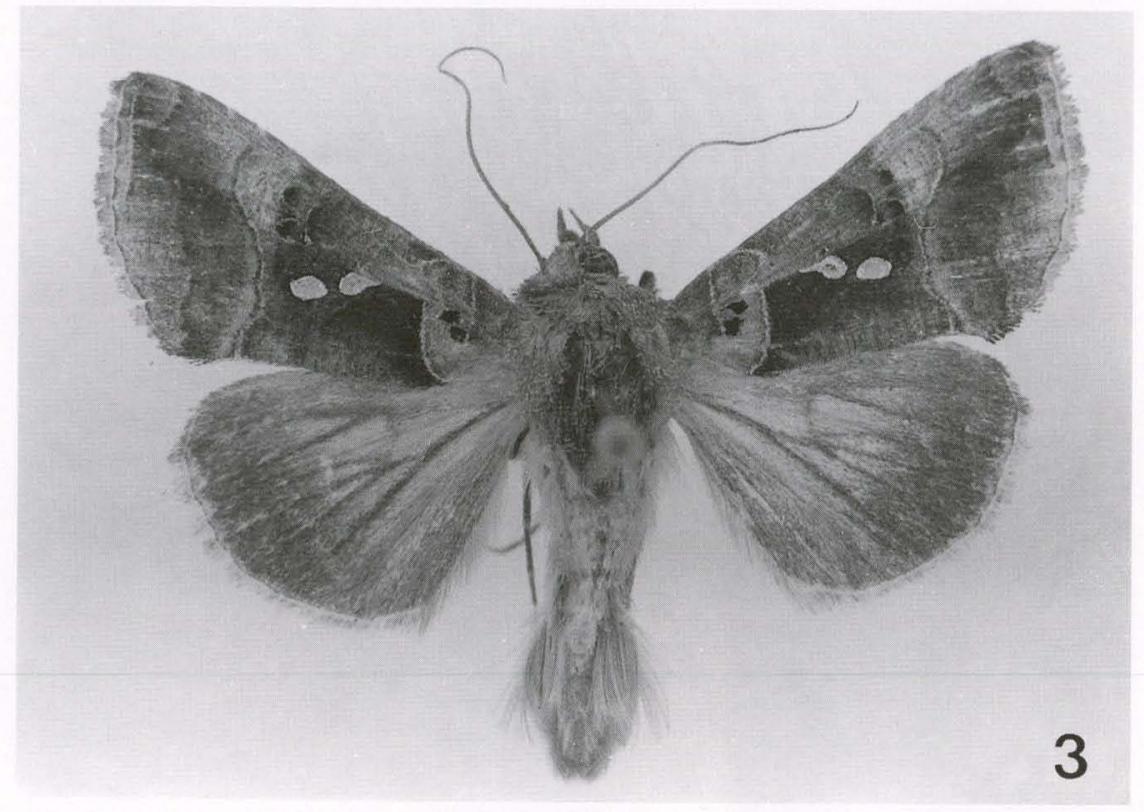

Fig. 3. Enigmogramma antillea sp. n., male, paratype, Cuba.

Remarks. This species is very similar to E. admonens (Walker, [1858]), and Ctenoplusia calceolaris (Walker, [1858]) which also occur in the Antilles, but easily distinguished by the pair of black dots at the base of forewings in $E$. antillea. This is the undescribed Enigmogramma species referred to by LAFONTAINE \& POOLE (1991: 41).

\section{REFERENCES}

Lafontaine, J.D. \& R.W. Poole. 1991. Noctuoidea, Noctuidae (part), Plusiinae. In: R. Dominick (Ed.).

The moths of America North of Mexico, 25.1. Washington, Wedge Entomol. Res. Found., 182p.

Recebido em 07.12.1999; aceito em 05.IV.2001. 